\title{
Turistik Konak İşletmelerinde Mutfağın Fiziksel Koşullarının Önemi: Safranbolu Yöresel Mutfak Mimarisi Üzerine Bir Araştırma
}

\author{
Sibel Ayyıldız \\ Karabük Üniversitesi \\ Eflani Meslek Yüksekokulu \\ orcid.org/0000-0003-0701-2445
}

\section{$\ddot{O} z$}

Bu çalışmanın amacı, büyük bir kısmı turistik işletmelere dönüştürülen Safranbolu konaklarının mutfak yapısın fiziksel, psikolojik, iş güvenliği ve ergonomik açıdan incelemektir. Ayrıca çalışmada, eskiden yaşam alanları olarak kullanılan konak mutfakları ile günümüzde işletmeler tarafından kullanılan mutfakların fiziksel koşullar bakımından karşılaştırılması amaçlanmıştır. Araştırma, nitel veriler kullanılarak, derinlemesine görüşme yöntemi ile yapılmıştır. Örneklem seçiminde kartopu örneklem yöntemi kullanılmıştır. Yarı yapılandırılmış görüşme formuna bağlı kalınarak, Safranbolu ilçesinde bulunan 15 farklı konak işletmecisi ile yüz yüze görü̧smeler yapılmıştır. Konak işletmelerinde yapılan gözlemler ve görüşmelerden elde edilen veriler katogorize edilerek betimsel analizler yapılmıştır. Elde edilen bulgulara göre; Safranbolu evlerinin ana mutfakları üst katta yer almaktadır. "Aşevi" olarak da adlandırılan bu alanlar ailenin yemek yediği "sofa"nın hemen yanındadır. "Hayat" olarak isimlendirilen yerde bulunan "kazan ocakları" alanı ise ziyafet yemekleri, ekmek yapımı ve kışlık yiyeceklerin yapıldığı daha

Gönderilme Tarihi 17.01.2019

$\underline{\text { Kabul Tarihi }}$

07.09.2019

büyük bir mutfaktır. Günümüzde ise; turizm işletmelerine dönüştürülen konak mutfakları en alt kata, "hayat "ve "müştemilat" denilen yerde konumlanmaktadır. İşletmelerin modifiye ettiği mutfakların çoğu endüstriyel ekipmanlarla donatılmıştır. Konaklarda bulunan mutfak ve "kiler", çoğu işletmeci tarafindan müşterilerin kalabileceği odalara dönüştürülmüştür. Safranbolu konakları eskiden doğal aydınlatma ve havalandırmaya sahipken, günümüz mutfakları teknolojik aydınlatma ve havalandırma ekipmanları ile donatılmıştır.

Anahtar Kelimeler: Mutfak, Turistik Konak İşletmeleri, Safranbolu Mutfak Mimarisi

\section{Importance of the Physical Conditions of the Kitchen in Touristic Mansions: A Research on the Design of Local Kitchen in Safranbolu}

\section{Abstract}

The purpose of this study is to examine the kitchen structure of Safranbolu mansions which are mostly turned into tourist enterprises in terms of physical, psychological, occupational safety and ergonomics Moreover, it is aimed to compare the traditional kitchens and the kitchens used by the tourism enterprises today in terms of physical conditions. Using a qualitative research method, the research was conducted by in-depth interviews. Snowball sampling method was used in the sample selection. Using a semi-structured interview form, face-to-face interviews were conducted with 15 mansion establishment operators in Safranbolu. Descriptive analyzes were made by categorizing the data obtained from observations and interviews conducted at the mansion establishments. The main kitchen in a Safranbolu house is located on the top floor. This area, which is called as "aşevi", are located next to "sofa" where the family dines. The "kazan ocaklart" which is located in the "Hayat" section is a big kitchen where banquet dishes, bread and winter food are prepared. Today, the kitchens of the Safranbolu mansions, which are now turned into tourism enterprises are located in the lower floors of the mansions which are called "hayat" and "müştemilat". Most of the kitchens which are modified are equipped with industrial 
equipments and supplies. The kitchens and "kiler" have been converted into rooms where the guests can overnight. While in the traditional Safranbolu mansions natural lighting and ventilation were used, in modified kitchens, there are technological lighting and ventilation equipment.

Keywords: Kitchen, Touristic Mansion Establishments, Safranbolu Kitchen Architecture

\section{Giriş}

Mutfak, yiyeceklerin hazırlandığı, pişirildiği, muhafaza edildiği, servisinin yapıldığı ve gerekli ekipmanların depolandığı bir alandır (Yıldırım \& Hacıbaloğlu, 2000: 2, Çekal, 2013: 63, Doğan ve Kalınkara, 2015: 111). İnsan hayatının temel taşlarından biri olan ve geçmişten günümüze farklı yapı ve şekillerde günlük hayatta yer bulan mutfak; ilk insanlar için bir mağaradan oluşurken, Rönesans döneminde yüksek tavanlı, gösterişli yapılara dönüşmüştür.

Günümüzde hem yaşam alanları olan evlerde, hem de olarak yiyecek-içecek hizmeti veren işletmelerde mutfaklar bulunmaktadır (Zencir, 2016: 1). Mutfak; gelir getirici özelliğinden dolayı otel işletmelerinin de en önemli bölümlerinden biri olarak kabul edilmektedir (Doğan ve Kalınkara, 2015: 111).

Yatak kapasitesinin önemli bir kısmının eski konakların konaklama tesisine dönüştürülmesi ile oluştuğu Safranbolu'da turizm faaliyetleri oldukça gelişmiştir. Restore edilerek turizm tesislerine dönüştürülen bu konak-oteller misafirlerine konaklama yanı sıra yiyecek içecek hizmeti de sunmaktadır. Ancak, bu konaklarda bulunan mutfakların, geleneksel olarak ailenin yeme-içme ihtiyacını karşılama fonksiyonu değişikliğe uğramış, yeni fonksiyonlar kazandırılarak ve yeni eklipmanlar eklenerek turistlere hizmet verir hale gelmiştir. Bu durum bu mutfakların fiziksel özelliklerinde değişikliğe neden olmuştur. Bu araştırmanın amacı Safranbolu'da faliyet gösteren konak-otellerin mutfaklarının fiziksel koşullarının incelenmesi ve değerlendirilmesidir.

\section{Kavramsal Çerçeve}

\subsection{Mutfak Kavramı ve Mutfağın Fiziksel Özellikleri}

"Mutfak" sözcüğü, Arapça "matbah"tan gelmektedir. Türkçe "ocak" sözcügünün ise etimolojik olarak "od-ak" (ateş yakılan yer) kökünden geldiği ileri sürülmektedir (Tez, 2015: 107). Tarihsel gelişim süreci içinde mutfak, üretime dayalı eylemleri, özel araç-gereç ve donanımıyla hem ekonomik ve teknolojik, hem de sosyokültürel açıdan daima önemli bir rol oynamıştır.

Mutfağın tarihi İnsanoğlunun ateşin keşfetmesi ile başlamıştır. İnsanlar besinlerin pişirildiğinde daha kolay parçalandığını ve sindirimin daha kolay olduğunu keşfetmişlerdir (Akın \& Gültekin, 2015: 55, Tez, 2015: 107). Mezopotamya'da insanların toplu halde yemek yiyebilmeleri için büyük mutfaklara ihtiyaç duyulmuş ve böylece evin ayrı bir bölümüne ilk mutfak inşa edilmiştir. Evlerin genellikle bir avluya inşa edildiği Antik Yunanda (M.Ö 1.000- M.S 30) yerleşim alanının ortasında kalan kısmı mutfak olarak kullanmıştır. Daha donanımlı mutfaklara sahip olan Romalılar, mutfaklarını ana binaya eklemiştir (Akın \& Gültekin, 2015: 61). 
Mutfakların fiziksel özellikleri ve konumu yemeğin verileceği yerin ve yapının çeşidine göre değişiklik göstermektedir. Mutfak bir yapının (binanın) genellikle alt katına, üst katına veya binanın dışına gerekli tesisatı donatılarak inşa edilir. Mutfaklarda özellikle havalandırma ve aydınlatma büyük önem taşımakta olup malzeme temini, çöp akışını sağlama ve tesisatlarda çıkabilecek arızalara müdahale edebilmek için mutfaklar uygun konumda inşa edilmelidir. Mutfak duvarları 1şığı iyi yansıtan, aydınlık gösteren boyalarla boyanmalı (genellikle beyaz) ve ışık $\mathrm{m}^{2}$ ye 50 watt düşecek şekilde olmalıdır. Son olarak mutfak tabanı kaymayan ve kolay temizlenebilen bir malzemeden yapılmalıdır (Merdol, 2015: 89).

Tasarım, çalışma ve yaşama koşullarının insan kullanımına uygun hale getirilmesini amaçlayan ergonomi, mutfağın düzenlenmesinde de önemli bir unsurudur. Ergonomi, kişilerin karşılaşabilecekleri bir takım tehlike olasılıklarını ortadan kaldırarak, insan hayatına uygun hale getirir ve yaşam kalitesini yükseltir. Fizyolojik özelliklere uygun çalışma düzeni, kullanılan araç ve gerecin işe ve kullanan kişiye uyumunun sağlanması ergonominin çalışma alanlarını oluşturur (Güler, 1997: 10, Akın \& Gültekin, 2015: 5). Bireylere uygun olarak tasarlanan mutfak donanımları, çalışma esnasında personelin yorulmasını ve zorlanmasını engelleyerek, konforu ve iş verimliliğini arttırır. Uygun olmayan mutfak donanımı ise kazalara, fiziksel ve mental rahatsızlıklara ve meslek hastalıklarına neden olabilmektedir. Bu durum çalışan personelin iş verimliliğini, işin sürdürülebilirliğini ve psiko-sosyal durumunu olumsuz etkilemektedir (Çekal, 2013: 65).

\subsection{Safranbolu Evleri ve Turizm Amaçlı Olarak Kullanılan Tarihi Konaklar}

Geçmişi Paleolitik çağlara kadar uzanan Safranbolu (Beyazıt, 2014: 1) önemli bir Osmanlı kentidir. Zengin kültürel geçmişi, sehrin Osmanlı İmparatorluğu döneminde ekonomik anlamda çok güçlü bir merkez olduğunu göstermektedir. Bu durumu kentte bulunan gösterişli, genellikle büyük ölçekli konaklarından da anlamak mümkündür.

Safranbolu'da bulunan, yapımı 18. yüzyıl sonu ve 19. yüzyıl başlarına tarihlenen ve "korunması gerekli kültür varlıkları" olarak tescillenen yaklaşık 1490 taşınmazın 1222 tanesini evler oluşturmaktadır (Anonim, 2018b, Ceylan \& Somuncu, 2016: 56, Dönmez vd. 2017: 779). Safranbolu'da evler yazlık ve kışlık olarak kullanılmıştır. 'Şehir' ya da 'Çarşı' olarak bilinen bölgede evler kışlık olarak kullanılırken; 'Bağlar' (Bağevleri) bölgesinde bulunan evler yazlık olarak kullanılmıştır (Anonim, 2018c, Özdemir, 2011: 26, Gezer, 2013: 18, Kılıç ve Türkoğlu, 2015: 262).

Safranbolu evleri ya da günümüzde ifade edildiği üzere konakları geleneksel Türk ailesinin yaşam kültürünü ve törelerini yansıtmaktadır. Safranbolu evleri; plan özellikleri, evlerdeki kat kullanımları, sofalar, haremlik selamlık odaları, kim geldi pencereleri, döner dolaplar, gömme dolapları, kapıları, kapı tokmakları vb. donatıları ile Türk sivil mimarisinin en iyi örnekleri arasında gösterilmektedir. İklim, kültür, aile yapısı ve sosyo-ekonomik durum Safranbolu evlerinin yapısını etkileyen en önemli unsurlardır (Tokol, 2014: 18, Bozkurt \& Altınçekiç, 2013: 81). Safranbolu'da ailelerin kalabalık olması ise evlerin tipolojisinde belirleyici olmuştur (Bozkurt \& Altınçekiç, 2013: 81). 
Safranbolu evlerinin tasarımında 1şığa ve doğal aydınlatmaya önem verilmiştir. Konaklar gün ışığını içeri aldığından psikolojik konfor sağlamaktadır. Planlamaya bağlı olarak yazın sıcak günlerinde odalar ve katlarda doğal bir sirkülasyon olduğundan, Safranbolu evlerinin iç mekanlarında konforlu bir ortam mevcuttur (Gezer, 2013: 27).

Tarihi konaklar turizm endüstrisinin gelişmesinde önemli bir yere sahiptir (Boz, 2017: 6). Bir ulusun kimliğini ve karakterini ortaya koyan (Tarihi Kentler Birliği, 2004: 312) tarihi konaklar, konaklama ve yeme-içme amaçlı tesislere dönüştürülmektedir. Böylece hem konağın otantik özelliklerinin ve fiziksel bütünlüğünün korunması hem de konak sahibine gelir getirmesi amaçlanmaktadır. Otantik özellikleri korunan konakların turistlere cazip geldiği ve tercih edilebilirliğin arttığı varsayılmaktadır (Türkan, 2013: 15, Türkay vd. 2017: 800).

Safranbolu'da 1980'lerden bu yana 132 tarihi yapının restore edilerek kullanıma açıldığı belirlenmiştir (Özdemir, 2011: 140). Türker (2013: 124)'e göre; Safranbolu'da Kültür ve Turizm Bakanlığı Turizm İşletme belgeli 1.039 yatağa sahip 19 otel ve Belediye belgeli 1.565 yatak kapasiteli 63 küçük otel ve konak bulunmaktadır. Safranbolu'daki konaklama işletmelerinin \% 93'ü restore edilmiş eski tarihi yapılardan oluşmaktadır. Bu konak otellerden iki örnek Fotoğraf 1 ve 2'de görülmektedir.

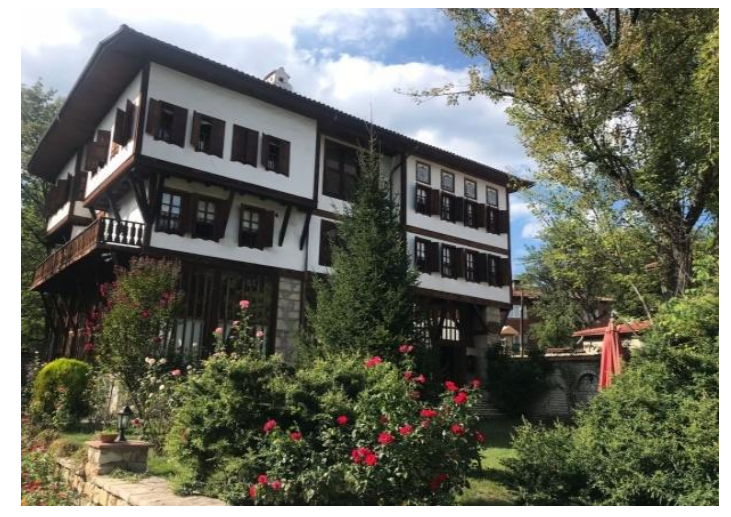

Fotoğraf 1. Asmazlar Konak/SafranboluBağlar

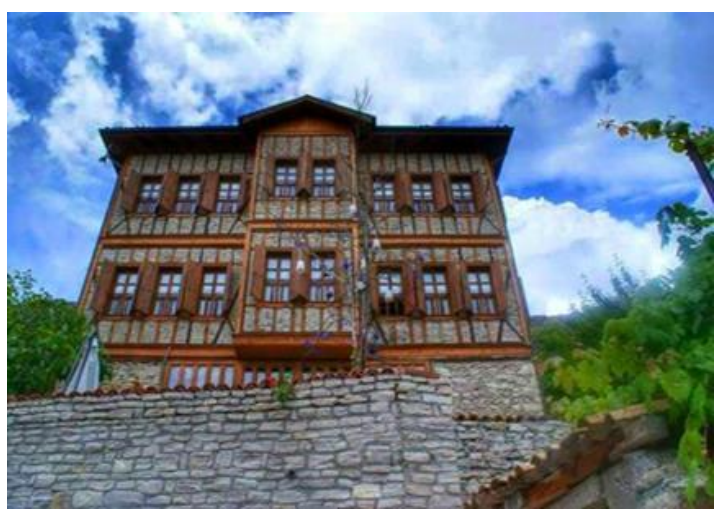

Fotoğraf 2. Dadibra Konak/ SafranboluEskiçarşı

\section{Yöntem}

Geleneksel olarak yaşam alanı olarak kullanılan konakların günümüzde turistik işletme amaçlı olarak kullanılması mutfağın yapısında fiziksel, psikolojik, ergonomik vb. özelliklerinde değişikliklere ve dolayısıyla da bazı sorunların ortaya çıkmasına neden olmuştur. Bu çalışmada, büyük bir kısmı turistik işletmelere dönüştürülen Safranbolu konaklarında bulunan mutfaklar fiziksel, psikolojik, iş güvenliği ve ergonomik açılardan incelenmiş ve geleneksel konak mutfakları ile günümüzde turizm işletmeleri tarafından kullanılan mutfakların fiziksel koşulları karşılaştırılarak değerlendirilmiştir. 
Çalışmada birincil ve ikincil (kitap, tez, makale v.b.) kaynaklardan yararlanılmıştır. Nitel bir yöntemin benimsendiği çalışmanın ampirik kısmında derinlemesine görüşme yöntemi kullanılmıştır. Ayrıca araştırmacının sahada yaptığı gözlemler de bu çalışmada önemli bir yer tutmaktadır. Araştırmanın evrenini Safranbolu ilçesinde bulunan konaklar ve konak-oteller oluşturmaktadır. Çalışma örnekleminin belirlenmesinde kartopu örnekleme yöntemi kullanılmış olup örneklem Safranbolu'da faaliyet gösteren 15 konak işletmesinden oluşmaktadır. İncelenen konakların 5'i Bağlar bölgesinde, 9,'u Eski Safranbolu'da, 1 tanesi ise Yörük Köyü'nde bulunmaktadır.

Yarı yapılandırılmış görüşme formunun kullanıldığı araştırmada konak işletmecileri ile yüz yüze görüşmeler yapılmıştır. Görüşmeler, 25 Mayıs - 23 Haziran 2018 tarihleri arasında gerçekleştirilmiş, ortalama 40-45 dakika süren görüşmeler ses kayıt cihazı ile kayıt edilmiştir. Görüşme formu, EK1'de verilmektedir.

Konak işletmelerinde yapılan gözlemler ve görüşmelerden elde edilen veriler betimsel olarak analiz edilmiştir. Betimsel analiz, elde edilen verilerin önce sistematik ve açık bir biçimde betimlenmesini, daha sonra yapılan bu betimlemelerin açıklanmasını, yorumlanmasını, neden-sonuç ilişkilerinin irdelenerek birtakım sonuçlara ulaşılmasını ifade eden bir nitel veri analizi türüdür (Yıldırım \& Şimşek, 2016: 239). Elde edilen veriler, temalara (ana başlıklara) ve kodlara ayrılarak yorumlanmıştır.

Çalışma; Fiziksel yapı, Ergonomik Yapı, Psikolojik Koşulların Uygunluğu ile İş Güvenliği ve Sağlık koşullarının Uygunluğu olarak 4 temadan oluşmuştur. Görüşme formundan yararlanılarak hazırlanan bu temalar mutfakta bulunması gereken 16 özelliği içermektedir. Çalışmada belirlenen temalar ve kodlar aşağıda verilmektedir.

\section{Tema 1-Fiziksel Yap1}

Kod-1 Mutfakta (azami) çıkan yemek sayısı (kaç kişilik)

Kod-2 Mutfağın konumunun diğer yaşam alanlarıyla uyumu

Kod-3 Mutfak aydınlatma gereçlerinin uygunluğu

Kod-4 Mutfağın yerleştirildiği cephenin uygunluğu

Kod-5 Mutfağın kiler veya depo ile mesafesinin uygunluğu

Kod-6 Mutfaktaki havalandırmanın uygun olması

Kod-7 Ocağın konumu ve yeterliliği

\section{Tema 2-Ergonomik Yap1}

Kod-1 Mutfakta bulunan çalışma tezgahları ve dolapların antropometrik özelliklere uygunluğu

Kod-2 Mutfak personeline yönelik rahatsız edici gürültü, toz, duman veya kimyasal gazlara karşı tedbirler alınması 


\section{Tema 3-Psikolojik Yapıya Uygunluk}

Kod-1 Mutfakta çalışan personelin kendini güvende hissetmesi

Kod-2 Mutfağın konumu ve aydınlatmasının personeli motive edici olması

Kod-3 Mutfağın rengi ve ferahlığının çalışanın ruhsal durumuna pozitif etkisi

\section{Tema 4-İs Güvenliği ve Sağlığa Uygunluk}

Kod-1 Mutfağın iş kazalarına karşı korunaklı olması

Kod-2 Meslek hastalığına neden olan fiziksel, biyolojik ve kimyasal faktörlere karşı mutfağın korunaklı olması

Kod-3 Mutfakta kullanılan tezgahların ve çalışma alanlarının periyodik hijyen ve sanitasyon işlemlerine uygunluğu

Kod-4 Yangın durumunda kullanılacak yeterli yangın söndürücü vb. ekipmanın bulunması

\section{Bulgular}

Çalışmada ağırlıklı olarak Eski Safranbolu'da (Çarşı) ve Bağlar bölgesinde faaliyet gösteren konak-oteller incelenmiştir İncelenen Eski Safranbolu'da bulunan konak işletmeleri; Dadibra Konak, Çamlı Konak Hatice Hanım Konağı, Antep Konağı, Şerbetçioğlu Konağı, Havuzlu Konak, Kadıoğlu Şehsade Konağı, Çakıroğlu Konağı ve Leyla Hanım Konağı'dır. Bağlar bölgesinde incelenen konak işletmeleri ise; Safir Konakları, Aymazlar Bağ Evi, Gökçüoğlu Konağı, Safran Konak, Şadiye Hanım Konağı'dır. Çalışmada ayrıca Yörük Köyü'nde faaliyet gösteren Kasım Sipahioğlu Konağ1 da yer almıştır. Kasım Sipahioğlu Konağını diğer konaklardan ayıran farkı; müşterilerin günü birlik ziyaret edebildiği, konaklama yapılamayan, 300 yıldır aynı ailenin yaşadığı, 750 yıllık tarihe sahip Kentsel Sit alanında yer almasıdır. Araştırmada yer alan konak işletmelerinin mutfakları aşağıda yer alan tema (ana başlık) ve kodlar ile incelenmiştir.

1-Fiziksel Koşullar: Çalışmanın birinci teması olan Safranbolu'daki konak işletmelerinin fiziksel koşulları ile ilgili kodlar; mutfakta çıkan -azami- yemek sayısı (kaç kişilik), mutfağın konumunun diğer yaşam alanlarıyla uyumu, mutfak aydınlatma gereçlerinin uygunluğu, mutfağın yerleştirildiği cephenin uygunluğu, mutfağın kiler veya depo ile mesafesinin uygunluğu, mutfaktaki havalandırmanın uygun olması, ocağın konumu ve yeterliliğidir.

Kod 1- Mutfakta çıkan -azami- yemek sayısı (kaç kişilik): Katılımcılardan K2, K6, K7, $\mathrm{K} 8, \mathrm{~K} 9, \mathrm{~K} 12$, K13 ve K14 işletmelerinde kahvaltı verdiklerini ve ortalama 15-20 kişilik yemek verebildiklerini belirtmişlerdir. K1, K3, K4, K10, K11 işletmelerini konaklama yanısıra Cafe/restoran olarak ve dügün organizasyonları için de kullandıklarını ifade etmişlerdir. Bu nedenle bu işletmelerin mutfak kapasiteleri daha büyüktür. Örneğin; K10, bu tür organizasyonlarda yaklaşık 500 kişilik yemek çıkardıklarını belirtmiştir. K15, konağını sadece gezi evi olarak kullanmaktadır. Bununla birlikte; konağın bahçesinde yer alan müştemilat mutfağa dönüştürülmüş olup burada ziyaretçilere gözleme, etli sarma, kiren şerbeti gibi yöresel lezzetler sunulmaktadır. 
Kod 2-Mutfağın konumunun diğer yaşam alanlarıyla uyumu: Mutfak (aş evi), eskiden konakların orta katında veya daha büyük evlerde en üst katta yer almaktaydı. Sofalarda tüm odalar birleşmekte ve burada, tuvaletler-abdest alanları ve kiler bulunmaktadır. Yeni yapılan kışlık ürünlerin dinlendirildiği ve cevizlerin havalandırıldığı dış çardak da mutfağın hemen yanı başında bulunmaktadır. Günümüzde ise; konak işletmeleri mutfağı ana binadan tümüyle ayırmıştır. Mutfakların konakların dışında bulunan müştemilatlara ya da kazan ocakları denilen yerlere taşındığı görülmektedir. Ana binada bulunan mutfakların ise konaklanacak odalara dönüştürüldüğü veya farklı amaçlar için kullanıldığı tespit edilmiştir. Bu mutfaklarda endüstriyel mutfak ekipmanları kullanılmaktadır. Ziyaretçilerin yemek kokularından ve mutfakta çalışırken ortaya çıkabilecek ses ve gürültüden rahatsız olamaları için mutfakların konakların dışına alındığı tahmin edilmektedir. Çünkü konaklar ahşap yapılar olduğundan yürürken oldukça fazla ses çıkmaktadır.

Kod 3-Mutfak aydınlatma gereçlerinin uygunluğu: Yapılan görüşmelerde konakların eskiden aydınlatma ile ilgili herhangi bir sorun yaşamadıkları belirlenmiştir. Safranbolu konakları doğal ışıktan azami ölçüde faydalanmaktadır. Günümüz konak işletmeleri, aydınlatma için odalarda ekstra bir tesisat eklenmemiştir. Dışarıda bulunan mutfakların pencere boyutları ve mimari özellikleri Safranbolu'nun geleneksel mimari yapısını yansıtmaktadır. Fakat mutfaklara ve dış mekanlara daha modern aydınlatma unsurları ilave edilmiştir.

Kod 4-Mutfağın yerleştirildiği cephenin uygunluğu: Safranbolu Eski Çarşıda bulunan konaklarda mutfakların kuzey cephesinde, Bağlarda bulunan konak mutfaklarının ise güney cephesinde konuşlandığ 1 belirlenmiştir. Katılımcılardan K1, K3 ve K9 yazın serin olduğu için insanların Bağlara göç ettiğini, kuzey daha serin olduğu için yaşam alanlarının kuzey cephesine inşa edildiğini belirtmişlerdir. Günümüzde ise konaklarda mutfak olarak düzenlenen alanın cephesi dikkate alınmamıştır.

Kod 5-Mutfağın kiler veya depo ile mesafesinin uygunluğu: Safranbolu konaklarında eskiden kiler veya depo mutfağın olduğu katta bulunmaktaydı. Ancak, günümüzde işletmeler mutfağı ve kileri konağın dışına inşa etmektedirler. Yapılan gözlemler konakların kiler veya depolarının mutfağa olan mesafesinin uygun olduğunu göstermektedir. Bununla birlikte kalabalık ziyaretçi gurupları ağırlayan işletmeler mutfak, kiler ve servis alanlarının yetersizliği ile ilgili sorun yaşadıklarını belirtmişlerdir. İşletmecilerden K5, K11 ve K13 bu durumu aşağıdaki gibi ifade etmektedir;

"Mutfaklarımız ve depolarımız küçük. Müşteriye servis yapıyoruz ancak boşları kaldıracak yerimiz yok. Personelimize giyinme alan ve ayr bir personel tuvaleti sağlayamıyoruz. Konak bahçesinde tüm bunlar için alan var ancak koruma kuralları gereği bu alanı kullanamadığımız için bu sıkıntıları çekmek zorunda kalıyoruz"

Kod 6- Mutfaktaki havalandırmanın uygun olması: Eskiden konak mutfaklarında doğal havalandırma olarak pencereler kullanılmaktayken, günümüzde mutfaklarda 
havalandırma endüstriyel ekipmanlar (davlumbaz, aspiratör) aracılığıyla yapilmaktadır.

Kod 7- Ocağın konumu ve yeterliliği: Safranbolu konaklarında eskiden üç ocak kullanılmaktaydı. Bunlardan ilki, ana mutfakta yer alan evin hanımının yemek ve ekmek yaptığı ocaklardır (Bkz. Fotoğraf 3). İkincisi ise konakların her odasında bulunan yemek yapmak veya ısınmak için kullanılan ocaklardır (Bkz. Fotoğraf 4). Son olarak kullanılan diğer ocaklar ise, konakların dışında yer alan kazan ocaklarıdır. Kazan ocaklarında genellikle yemek, kışlık gıda ürünleri hazırlığı ve ekmek yapılmaktadır. Bu ocakların günümüzde dekoratif amaçlı kullandığı görülmektedir. Dönüştürülen mutfaklarda endüstriyel ve ankastre ocaklar kullanılmaktadır.

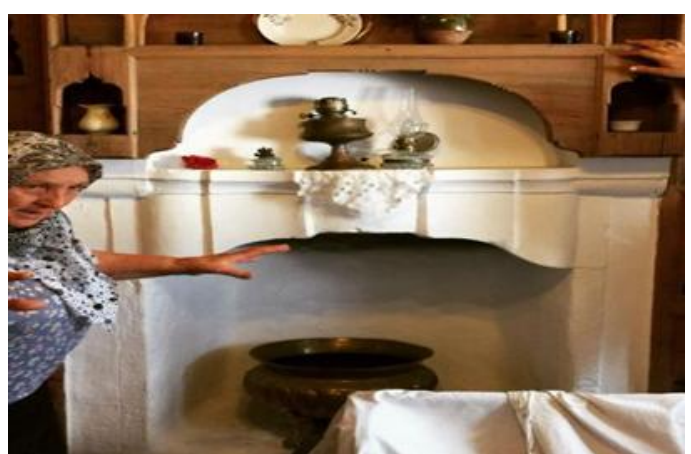

Fotoğraf 3. Kasım Sipahioğlu Konağında Ocak

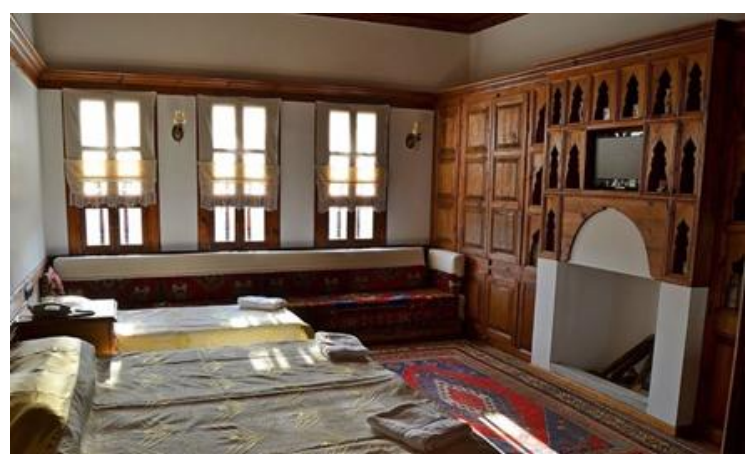

Fotoğraf 4. Fotoğraf 4: Leyla Hanım Konağında Bulunan Dekoratif Amaçlı Ocak

2- Ergonomik Yapı: Çalışmanın ikinci temasında, mutfakta bulunan çalışma tezgahları ve dolapların antropometrik özelliklere uygunluğu ve mutfak personeline yönelik rahatsız edici gürültü, toz, duman veya kimyasal gazlara karşı tedbirler alınması ile ilgili olan Ergonomik yapı incelenmiştir.

Kod 1- Mutfakta bulunan çalışma tezgâhları ve dolapların antropometrik özelliklere uygunluğu: İncelenen tüm konak işletmelerinde mutfak dolapları ve tezgahlarının çalışanların antropometrik özellikleri dikkate alınarak üretilen modern donatılara sahip olduğu belirlenmiştir. Konaklarda yaşayanların ve personelin daha rahat çalışabilmesi ve verimli bir iş akışının oluşabilmesi için daha modern donatılar kullanılmaktadır. Ayrıca eski donatıların kalabalık ziyaretçilere hizmet verebilecek yeterlilikte olmadığı belirlenmiştir. Eskiden ahır ve depo olarak kullanılan "hayat"1 bölümü, günümüzde lobi ve restoran olarak hizmet vermektedir (Bkz. Fotoğraf 5).

\footnotetext{
${ }^{1}$ Hayat: Konakların girişinde yer alan bölümdür. Hayat bölümünde hayvanların konulduğu ahır, samanlık gibi alanlar ile evin hanımının kullandığı kazan, ocak ve ambar (kiler) gibi mekânlar bulunur (Beyazit, 2014: 8).
} 


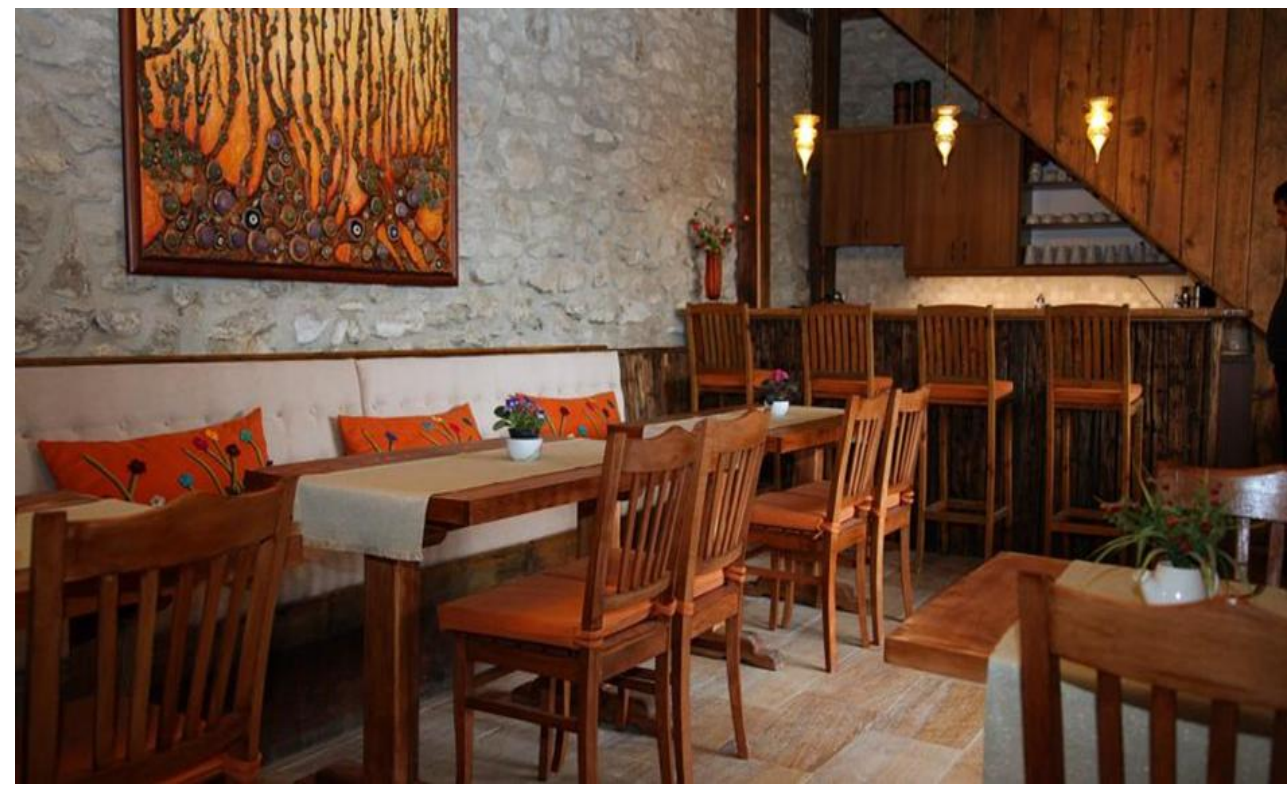

Fotoğraf 5. Dadibra Konak

Kod 2-Mutfak personeline yönelik rahatsız edici gürültü, toz, duman veya kimyasal gazlara karşı tedbirlerin alınması: Yapılan görüşmelerde katılımcıların bu konuda aynı görüşe sahip oldukları, geçmişte ve günümüzde toz, duman, kimyasal gaz gibi rahatsızlık verebilecek bir durum ile karşılaşılmadığı tespit edilmiştir.

3-Psikolojik Yapıya Uygunluk: Çalışmanın bu kısmında mutfakta çalışan personelin güven duygusu, mutfağın fiziksel özelliklerinin personelin motivasyonuna ve ruhsal durumuna olan etkisi incelenmiştir.

Kod 1-Mutfakta çalışan personelin kendini güvende hissetmesi: Konak işletmecileri mutfaklarının her anlamda güvenli olduğunu belirtmektedirler. Güvenlik ile ilgili olarak, yangına karşı mutfakta yangın tüplerinin olduğu, gaz kaçağına karşı ise alarm sisteminin bulunduğu belirlenmiştir.

Kod-2 Mutfağın konumu ve aydınlatmanın personeli motive edici olması: Konak mutfaklarında aydınlatmanın doğal yollarla yani pencerelerle yapıldığı ayrıca modern aydınlatmalarla da desteklendiği görülmektedir. Konak mutfaklarında personelin çalışma performansını olumsuz etkileyecek herhangi bir durum tespit edilmemiştir.

Kod-3 Mutfağın rengi ve ferahlığının çalışanın ruhsal durumuna pozitif etkisi: Safranbolu konaklarının mutfakları genellikle açık renkli fayanslar ve endüstriyel ekipmanlarla donatılmıştır. Mutfağın rengi ile ilgili olarak personelin ruhsal durumunu olumsuz etkileyecek herhangi bir durum mevcut değildir. Fakat işletmeciler mutfağın genişliği ve ferahlığı ile ilgili olarak sıkıntılar yaşadıklarını vurgulamışlardır. Özellikle K1, K5, K10, K11, K13 mutfakta rahat çalışacak bir ortam sağlamanın zor olduğunu, çalışma alanlarının yetersiz olduğunu belirtmektedirler. Katılımcılar bu durumu şöyle ifade etmektedirler;

"Konaklar yaşam alanı olarak düşünülüp sonradan işletmeye dönüştürüldüğünden özellikle mutfak kısmında problemler yaşıyoruz. Bütün yemekleri aynı alanda pişirmek ve 
servise hazırlamak zorundayız. 4 personel aynı anda çalışamıyor, iş akışında problemler yaşıyoruz. Bu nedenle personel stresli çalışıyor. Servis istasyonunuz yok, fakat kullanılması mümkün olmayan oldukça büyük bahçelerimiz var. En azından konaklardaki kot alt olan yerlerin ya da merdiven altlarını kullanılmasina izin verilmesi gerekir. Mutfakların genişletilmesi için müsaade edilmediği gibi bahçelerin üstünün kapatılmasına da izin verilmiyor. Bu nedenle, toplantı ve dü̈̆̈̈n, nişan gibi organizasyonlarda da büyük sıkıntılar yaşıyoruz"

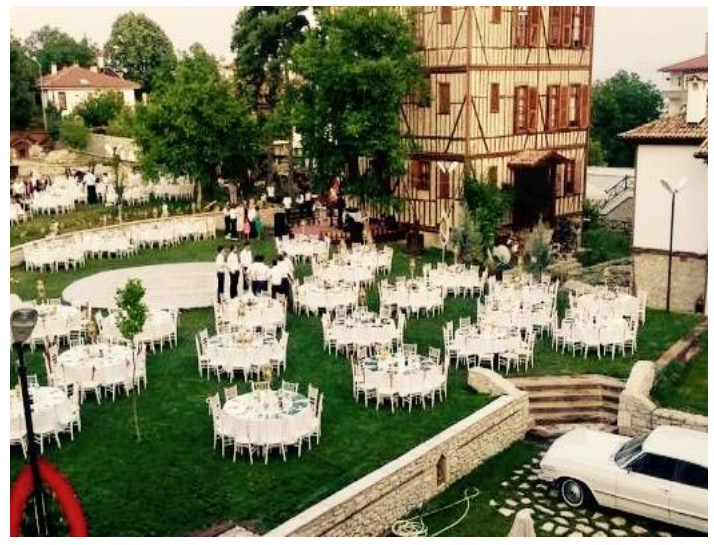

Fotoğraf 6. Safir Konakta Bir Organizasyon

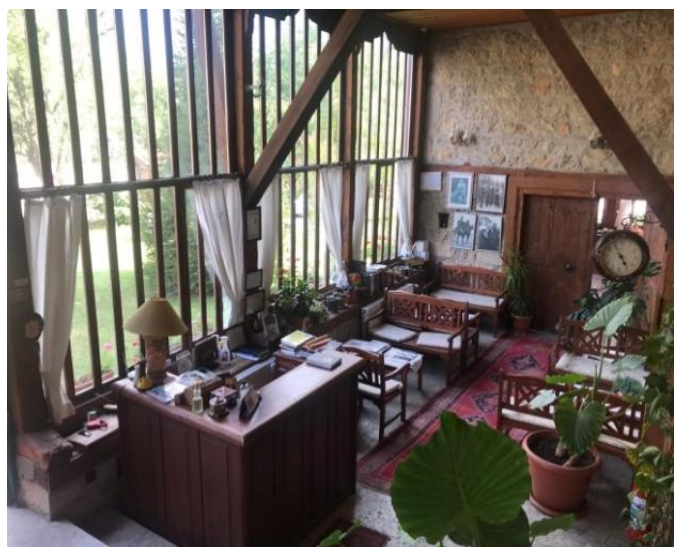

Fotoğraf 7. Asmazlar Bağ Evi

İşletmelerin bu konudaki sorunlarının ticari kaygılardan ve daha çok müşteri ağırlayarak daha fazla gelir elde etme isteğinden kaynaklandığı düşünülmektedir. Katılımcılar ile yapılan görüşmelerde kültürel mirasın korunması ve sürdürülebilirliğinin önemi vurgulanmıştır. Ancak, işletmecilik yapan konak sahiplerinin bu konuya daha duyarlı yaklaştıkları, kiralık konak işletenlerin ise daha çok gelir odaklı oldukları tespit edilmiştir. Konakları kendilerine ait olan işletmecilerin aşağıda sunulan görüşleri konuya olan yaklaşımlarını ifade etmektedir;

"Biz zaten sayı olarak fazla ziyaretçi istemiyoruz, biz bilinçli ve nitelikli ziyaretçiler ağırlamak istiyoruz"

4-İş Güvenliği ve Sağlığa Uygunluk: Çalışmanın son teması; mutfağın iş kazalarına karşı korunaklı olması, meslek hastalığına neden olan fiziksel, biyolojik ve kimyasal faktörlere karşı mutfağın korunaklı olması, mutfakta kullanılan tezgahların ve çalışma alanlarının periyodik hijyen ve sanitasyon işlemlerine uygunluğu, yangın durumunda kullanılacak yeterli yangın söndürücü vb. ekipmanın bulunması alt başlıkları ile incelenmiştir.

Kod 1-Mutfağın iş kazalarına karşı korunaklı olması: Konakların iş güvenliği konusunda sürekli denetlendiği ve işletmelerin bir iş güvenliği uzmanı ile birlikte çalıştığ başladığında iç kontrollerini yaptıkları ve tehlike arz eden durumlar için gerekli tedbirleri aldıkları belirlenmiştir. Konakların büyük bir kısmının ahşap olması 
nedeniyle özellikle mutfağın, bacaların, su ve elektrik tesisatlarının rutin kontrollerden geçirildiği tespit edilmiştir.

Kod 2-Meslek hastalığına neden olan fiziksel, biyolojik ve kimyasal faktörlere karşı mutfağın korunaklı olması: İşletmeler, personel alımlarında işgörenlerden sağlık raporu ve portör muayenesi istemektedirler. Ayrıca yapılan görüşmelerde konaklarda ilaçlama yapıldığı belirlenmiştir. Katılımcılar, zehirlenme, cilt hastalıkları, alerjik rahatsızlıklar vb. gibi sorunlarla daha önce karşılaşmadıklarını belirtmişlerdir. Katılımcılar bu durumu şöyle açıklamaktadırlar;

"Konaklar oldukça güzel ve nezih bahçeler içerisinde bulunmaktadır. Personel bu bahçelerde yemeğgini yer, sohbetini eder yani çalş̧anlar aile gibidir. Ayrıca Burada diğer bölgelerde olduğu gibi yoğun bir müşteri sirkülasyonu yok. Üstelik misafirlerimiz yillardır gelen daimi misafirler. Bu nedenle ilişkiler oldukça samimidir. Çalışanların mutsuz olması için hiçbir sebep yok"

Kod-3 Mutfakta kullanılan tezgahların ve çalışma alanlarının periyodik hijyen ve sanitasyon işlemlerine uygunluğu: Safranbolu'da konak mutfaklarında endüstriyel ekipmanlar ve tezgahlar kullanıldığından, periyodik hijyen ve sanitasyon işlemlerinin kolaylıkla yapılabildiği tespit edilmiştir.

Kod-4 Yangın durumunda kullanılacak yeterli yangın söndürücü vb. ekipmanın bulunması: Katılımcılarla yapılan görüşmelerde gerek mutfak gerekse konakların diğer alanları ile ilgili en çok dile getirilen sorunlar su, elektrik ve yangın olasılığı olmuştur. Tüm katılımcılar alt yapı ile ilgili sıkıntılar yaşadıklarını dile getirmişlerdir. Özellikle elektrik ve elektrikli aletlerin ortaya çıkarabileceği yangın tehlikesi işletmecilerde ciddi bir endişe yaratmaktadır. Konakların turizm işletmesine dönüştürülmesi sürecinde elektrik tesisatının uzman bir elektrikçi tarafından döşenmemesi, tesisatın kapasitesinin çok üzerinde elektrikli ekipman (her odaya bir kettle, mikrodalga fırınlar, küçük mutfak aletleri, saç kurutma cihazı vb.) kullanılması işletmecileri kaygılandırmaktadır. Katılımcılar bu durumu aşağıdaki gibi ifade etmektedirler;

"Siz kendi konağınız ile ilgili ne kadar önlem alırsanız alın, komşu konakta yangın çıkması geri dönülmesi imkansız felaketlere sebep olabilir"

Eski Çarşıda bulunan konak işletmeleri bu konudaki sıkıntılarını şöyle ifade etmektedirler;

"Sokaklar zaten çok dar. Bu da yetmezmiş gibi park sorunu nedeniyle misafirler olmadık yerlere araba park ediyorlar. Dolayısıly yangın anında müdahale imkanı oldukça zorlaşıyor. Sadece konaklardaki yangin söndürme araçlarılla ne kadar müdahale edilebilir bilemiyoruz."

\section{Sonuç ve Öneriler}

Safranbolu'da bulunan konak-otel işletmeleri mutfaklarının fiziksel özelliklerini belirlemek ve geleneksel mutfak ile günümüzdeki mutfak organizasyonunu karşılaştırmak amacıyla yapılan bu araştırmada 15 konak işletmecisi ile görüşülmüş ve 
konak işletmelerinin daha rahat bir ortam yaratmak ve iş akışını hızlandırabilmek için mutfağı ana binanın tamamen dışına konumlandırdığı belirlenmiştir. Bu mutfaklar endüstriyel ekipmanlar ile donatılmıştır. Safranbolu geleneksel ev mimarisinde kazan ocağ1 olarak ifade edilen ocakların bulunduğu yerler ile konak girişlerinde bulunan "hayat" günümüzde yemek salonlarına dönüştürülmüştür.

Mutfaklarda kullanılan ocak, çalışma tezgahları ve dolapların antropometrik özellikte olduğu, havalandırma ve aydınlatma gibi unsurların konakların geleneksel özelliklerine kıyasla daha teknolojik donatılara sahip olduğu belirlenmiştir. Bu bağlamda personelin daha rahat çalışabilmesi ve verimli bir iş akışının yürütülebilmesi için konak mutfaklarının hem fiziksel hem de psikolojik olarak uygun olduğu görülmektedir.

Konak mutfakları iş kazalarına ve meslek hastalıklarına neden olan fiziksel, biyolojik ve kimyasal faktörlere karşı korunaklıdır. Mutfak ekipmanları ve çalışma alanları periyodik hijyen ve sanitasyon işlemlerine uygundur.

Konaklar ahşap yapılar olduğundan mutfak bölümünde çıkabilecek olası bir yangın büyük bir felakete neden olacaktır. İşletmeciler, yangına karşı önlemler almalarına rağmen konakların birbirine yakın olması ve yangına karşı müdahale durumunda konakların bulunduğu sokakların dar olması gibi olumsuzluklar işletmecilerde büyük endişe yaratmaktadır.

İşletmelerin yaşadıkları en önemli sorunların başında mutfaktaki alanların yetersiz olması gelmektedir. Mutfakların küçük olması nedeniyle özellikle ziyafet yemeklerinde personel büyük sorunlar yaşamaktadır. Bunun en temel nedeni konakotellerin küçük konaklama tesisleri olması nedeniyle işletmecilerin daha fazla gelir elde etme isteğidir. Konak sahibi işletmecilerin ekonomik çıkarların da ötesinde kültürel miras, doğal yapıların korunması ve turizm konularında daha duyarlı ve bilinçli oldukları belirlenmiştir.

Araştırmadan elde edilen bu sonuçlardan yola çıkarak aşağıdaki öneriler geliştirilmiştir;

- Konak mutfakları, koruma ilkeleri dikkate alınarak mevcut alanlardan maksimum fayda sağlayacak şekilde planlanmalıdır. Mutfak personele rahat çalışabileceği ve iyi bir iş akışı sağlayacak bir ortam sunmalıdır. Bu nedenle mutfak planı mutlaka bir uzman tarafindan yapılmalıdır.

- Konaklar turizm işletmesine dönüştürülmeden önce iyi tasarlanmalı, gelecekteki müşteri potansiyeli düşünülerek planlanma yapılmalıdır.

- Korunması gerekli kültür varlığı olarak tescil edilen konaklarda, yangın güvenliği ile ilgili planlama mevcut alt yapı dikkate alınarak yapılmalıdır. Ayrıca işletme sahiplerine ve çalışan personele yangın ile ilgili eğitimler verilmelidir.

- Daha fazla kar elde etmek amaciyla Safranbolu'nun kentsel dokusunu ve özgünlüğünü bozacak her türlü yaklaşımdan kaçınılmalıdır. Sürdürülebilir bir 
turizm için bu kültürel miras yalnızca kurumsal anlamda değil bireysel olarak da bilinçli bir şekilde korunmalıdır.

- Kentin taşıma kapasitesini aşan ziyaretçi sayısı yerine destinasyona nitelikli ziyaretçi çekmek amacı ile farklı etkinlikler düzenlenmelidir. Örneğin; gastronomik aktiviteler yapılabilir. Konakların hayat bölümünde bulunan kazan ocakları Gastronomik workshop etkinlikleri için oldukça uygundur. Ziyaretçilerle birlikte bölgeye ait yöresel ekmek veya bazı spesifik yöresel yemekler yapılabilir. Safranbolu'nun yöresel "Çavuş üzümü bağ bozumu” şenlikleri ve "Safran hasadı" turistik turlarla desteklenerek ziyaretçilere farklı deneyimler yaşatılabilir. Bu gastronomik etkinlikler hem bölgenin mutfak kültürünün hem de destinasyonun sürdürebilirliğine katkı sağlayacaktır.

\section{Kaynakça}

Akın, G. ve Gültekin, T. (2015). Ergonik Restoran Tasarımı ve Güvenliği, Ankara: Ankara Üniversitesi Basımevi.

Anonim, (2018a). Safranbolu'da Turizm, Karabük İl Kültür ve Turizm Müdürlüğü, 3 Eylül 2018 tarihinde http: //www.karabukkulturturizm.gov.tr adresinden erişildi.

Anonim, (2018b). Safranbolu Evleri Fotoğrafları, 33 Eylül 2018 tarihinde http: //www.safranboluevleri.org adresinden erişildi.

Anonim, (2018c). Safranbolu Evleri, Safranbolu Ticaret ve Sanayi Odası, 2 Eylül 2018 tarihinde http: //www.safranbolutso.org.tr/safranbolu-evleri adresinden erişildi.

Ayaz, N., Apak, C. ve Sünbül, K. (2018). Kültürel Miras Alanları Üzerine Bir Meta Analizi: Safranbolu İlçesi Örneği, Türk Turizm Araştırmaları Dergisi, 2(1): 1-14.

Beyazıt, N. (2014). Safranbolu Evlerinin Plan Tipolojisi ve Kullanıcı İhtiyaçları Hiyerarşisi, Tasarn Kuram Dergisi, 10(17): 1-15.

Bozkurt, S.G. ve Altınçekiç, H. (2013). Anadolu'da Geleneksel Konut ve Avluların Özellikleri ile Tarihsel Gelişiminin Safranbolu Evleri Örneğinde İrdelenmesi, Journal of the Faculty of Forestry, 63(1): 69-91.

Boz, M. ve Uğur, İ. (2015). Tarihi Kentler Ve Turizm: Konaklama İşletmeleri Yöneticilerinin Safranbolu'da Turizm Gelişimine İlişkin Algiları. $2^{\text {nd }}$ International Congress of Tourism $\mathcal{E}$ Management Researches, Kuşadası, 1-37.

Bozkurt, S.G. (2013). 19.yy da Osmanlı Konut Mimarisinde İç Mekan Kurgusunun Safranbolu Evleri Örneğinde İrdelenmesi, Journal of the Faculty of Forestry, 62(2): 37-70.

Ceylan, S., ve Somuncu, M. (2016). Kültür Turizmi Alanlarında Turizmin Çeşitlendirilmesine Eleştirel Bir Bakış: Safranbolu UNESCO Dünya Miras Alanı, Uluslararası Türk Dünyası Turizm Araştırmaları Dergisi, 1(1): 53-64.

Çekal, N. (2013). Yiyecek İçecek İşletmelerinde Mutfak Tasarımında Dikkat Edilmesi Gereken Faktörler, e-Journal of New World Sciences Academy NWSA-Social Sciences, 8(1): 62-66.

Doğan, M. D. ve Kalınkara, V. (2015). Konaklama İşletmeleri Mutfak Çalışanlarının Antropometrik Ölçüleri ve Optimum Mutfak Donanımı Tasarımı, Süleyman Demirel Üniversitesi Mühendislik Bilimleri ve Tasarm Dergisi, 3(3): 111-119. 
Dönmez, Y., Öztürk, M., Gökyer, E. ve Türkmen, F. (2017). Korunan Alanlarda Koruma Kurallarının Turizme Olan Etkileri: Safranbolu Örneği. 1st International Sustainable Tourism Congress, Kastamonu, 778-784

Gezer, H. (2013). Geleneksel Safranbolu Evlerinin Sürdürülebilirlik Açısından Değerlendirilmesi, İstanbul Ticaret Üniversitesi Fen Bilimleri Dergisi, 12(23): 13-31.

Güler, Ç. (1997). Ergonomiye Giriş. Ankara: Aydoğdu Ofset.

Kılıç, S. E. ve Türkoğlu, G. (2015). Conservation Problems of Traditional Housing with Continued Original Function and Recommended Solutions: Safranbolu "Eski Çarşı District", Megaron, 10(2): 260-270.

Merdol, T. K., (2015). Toplu Beslenme Yapılan Kurumlarda Mutfak ve Yemekhane Planlanması, Toplu Beslenme Servisi, Sağlıklı Yönetim Rehberi. Ankara: Hatipoğlu Yayınevi.

Tarihi Kentler Birliği Yayın Organı, (2004), Yerel Kimlik Dergisi, 309-319. 23 Ağustos 2018 tarihinde http://www.tarihikentlerbirligi.org/yayinlar/yerel-kimlik/ adresinden erişildi.

Tez, Z. (2015). Lezzetin Tarihi, Geçmişten bugüne yiyecek, içecek ve keyif vericiler, İstanbul: Hayykitap.

Tonguç, T. (2014). Geleneksel Türk Evlerinde Yalınlık, Safranbolu Kaymakam Evi Örneğinde İç Mekan Donatıları, Sanat - Tasarım Dergisi, 5:15-24.

Türkan, O. (2013). Beypazarı İlçesinin Turizm Potansiyeli ve Turizm Faaliyetlerine Yönelik Önerileri, Gazi Üniversitesi Endüstriyel Sanatlar Eğitim Fakültesi Dergisi, 32: 12-25.

Türkay, O., Genç, K. ve Şengül, S. (2017). Tarihi Konak İşletmeciliğinde Yatırım Sürecinin Sorunları: Mudurnu Örneği. Uluslararası Sosyal Araștırmalar Kongresi (USAK'17), İstanbul, 800-806.

Türker, N. (2013). Host Community Perceptions of Tourism Impacts: A Case Study on the World Heritage City of Safranbolu, Turkey, Revista de Cercetare Si Interventie Sociala, 43: 115-141.

Özdemir, Ü. (2011). Safranbolu'nun Kültürel Miras Kaynakları ve Korunması, Doğu Coğrafya Dergisi, 26: 129-142.

Öztürk, Ö. (2018). Safranbolu Tarihi; Dadybra, Zalifre, Zağfiranbolu(Karabük), Özhan Öztürk Makaleleri, 7 Ağustos 2018 tarihinde http: //ozhanozturk. com/2018/01/06/ safranbolutarihi/ adresinden erişildi.

Yıldırım, K. ve Hacıbaloğlu, M. (2000). Konut Mutfakları İle İlgili Ergonomik Bir Araştırma, Gazi Üniversitesi Fen Bilimleri Enstitüsü, 13(3).

Yıldırım, A. ve Şimşek, H. (2016). Sosyal Bilimlerde Nitel Araştırma Yöntemleri. Ankara: Seçkin Yayıncilik.

Zencir, E. (2016). Temel Mutfak Teknikleri. Eskişehir: Anadolu Üniversitesi Yayınları. 


\section{Görüşme Yapılan Konak İşletmeleri}

\begin{tabular}{|c|c|c|}
\hline Konak İşletmeleri & Bulunduğu Bölge & Adres \\
\hline Safir Konakları & Bağlar & $\begin{array}{l}\text { Bağlarbaşı Mahallesi, Köyiçi Meydanı Arslanlar Cd. } \\
\text { No:2 Bağlar - Safranbolu }\end{array}$ \\
\hline Asmazlar Bağ Evi & Bağlar & Bağlarbaşı Mahallesi, Değirmenbaşı Sk., Safranbolu \\
\hline Gökçüoğlu Konağı & Bağlar & $\begin{array}{l}\text { Bağlarbaşı Mahallesi, Değirmenbaşı Sk No:13, } \\
\text { Safranbolu }\end{array}$ \\
\hline Safran Konak & Bağlar & Bağlarbaşı Mahallesi, Köyiçi Sk. No:1, Safranbolu \\
\hline Şadiye Konağı & Bağlar & $\begin{array}{l}\text { Bağlarbaşı Mahallesi, Kurtuluş Cd. No:38, } \\
\text { Safranbolu }\end{array}$ \\
\hline Dadibra Konak & Eski Çarşı & Akcasu Mah. Altug Sok. No:21, Safranbolu \\
\hline Hatice Hanım Konağı & Eski Çarşı & Baba sultan mah, Naip Tarlası Sk no4, Safranbolu \\
\hline Antepler Konağ1 & Eski Çarşı & $\begin{array}{l}\text { Baba Sultan Mah.Naip Tarlası Sok. } \\
\text { Safranbolu }\end{array}$ \\
\hline Şerbetçi Konak & Eski Çarş1 & Akçasu Mahallesi, Akçasu Sk. No:29, Safranbolu \\
\hline $\begin{array}{l}\text { Havuzlu Asmazlar } \\
\text { Konağı }\end{array}$ & Eski Çarşı & Hacıhalil Mahallesi, Beybağ 1 Sk No:18, Safranbolu \\
\hline $\begin{array}{c}\text { Kadıoğlu Şehzade } \\
\text { Konakları } \\
\end{array}$ & Eski Çarşı & Hacı Halil Mahallesi, Mecit Sok No:24, Safranbolu \\
\hline Çakıroğlu Konakları & Eski Çarşı & Çeşme Mahallesi, 12, Celal Bayar Cd., Safranbolu \\
\hline Leyla Hanım Konağı & Eski Çarşı & $\begin{array}{l}\text { Çeşme Mahallesi Hükümet Sokak, No: 25, Kent } \\
\text { Tarihi Müzesi Yanı, Safranbolu }\end{array}$ \\
\hline Çamlı Konak & Eski Çarşı & $\begin{array}{l}\text { Hacı Halil Mahallesi Çelik Gülersoy caddesi no:5 } \\
\text { Safranbolu }\end{array}$ \\
\hline $\begin{array}{l}\text { Kasım Sipahioğlu } \\
\text { Konağı }\end{array}$ & Yörük Köyü & Kasımsipahioğlu Konağı, Yörüköyü Safranbolu \\
\hline
\end{tabular}

EK-1

\section{TURİSTIK KONAK İŞLETMELERINDE MUTFAĞIN FİİKSEL KOŞULLARININ ÖNEMİ: SAFRANBOLU YÖRESEL MUTFAK MIMARISII ÜZERINE BİR ARAŞTIRMA}

\section{Öğr. Gör. Sibel AYYILDIZ}

İşletmenin adı:

İşletmenin Faaliyet Süresi:

\section{A- Fiziksel Yapı}

1- Mutfakta (azami) kaç kişilik yemek çıkartılabiliyor?

2-Mutfağın konumu diğer yaşam alanlarıyla uyumlu mudur?

3-Mutfağın aydınlatma gereçleri uygun mudur?

4-Mutfağın yerleştirildiği cephe uygun mudur?

5-Mutfağın kiler veya depo ile mesafesi uygun mudur?

6-Mutfağın havalandırması uygun mudur?

7-Ocağın konumu uygun mudur, ocak yeterli midir? 


\section{B- Ergonomik Yap1}

1-Mutfakta bulunan çalışma tezgahları ve dolaplar çalışacak kişilerin antropometrik özelliklerine uygun mudur?

2-Mutfak personeline yönelik rahatsız edici gürültü, toz, duman veya kimyasal gazlara karş1 tedbirler alınmış mıdır?

\section{C- Psikolojik Yapıya Uygunluk}

1-Mutfak çalışan personelin kendini güvende hissettiği bir yer midir?

2-Mutfağın konumu, aydınlatması personeli motive edici koşullar içermekte midir?

3-Mutfağın rengi ve ferahlığı çalışanın ruhsal durumunu pozitif etkiliyor mu?

\section{D-İș Güvenliği ve Sağlığa Uygunluk}

1-Mutfak iş kazalarına karşı korunaklı mıdır?

2-Meslek hastalığına neden olan fiziksel, biyolojik ve kimyasal faktörlere karşı mutfak korunaklı midir?

3-Mutfakta kullanılan tezgahlar ve çalışma alanları periyodik hijyen ve sanitasyon işlemlerine uygun mudur?

4-Yangın durumunda kullanılacak yeterli yangın söndürücü vb. ekipman mevcut mudur? 